\title{
RESOLUTION OF A RACEMIC ISOLEUCINE MIXTURE BY USING METHYL L- MANDELATE
}

\author{
Rani Maharani*, Ace Tatang Hidayat, Dadan Sumiarsa, Achmad Zainuddin, Ika Wiani Hidayat \\ Department of Chemistry, Faculty of Mathematics and Natural Sciences, Universitas Padjadjaran, Jalan Raya \\ Bandung-Sumedang km. 21 Jatinangor 45363 West Java Indonesia \\ *Alamat Korespondensi: r.maharani@unpad.ac.id
}

Abstract: A methyl ester of L-mandelic acid was found to be an effective resolving agent for resolution of commercial DL-isoleucine. The resolution was based on Steglich esterification between methyl L-mandelate and Boc-DL-isoleucine. The two resolved isomers were easily separated by using a conventional flash-column chromatography, giving quantitatively good yields. Unfortunately, the methyl L-mandelate was found to be ineffective to resolve four stereoisomers of Fmoc- isoleucine.

Keywords: Methyl L-mandelate, Boc-DL-isoleucine, Fmoc-isoleucine, Steglich esterification

Abstrak: Ester metil L-mandelat diketahui merupakan agen pemisah yang efektif dalam resolusi campuran rasemat DL-isoleusin komersial. Proses resolusi didasarkan pada reaksi esterifikasi Steglich antara metil L-mandelat dan Boc-DL-isoleusin. Dua stereoisomer yang telah dipisahkan dapat dengan mudah dipisahkan dan menghasilkan produk dengan perolehan hasil yang baik. Sayangnya, metil L-mandelat diketahui tidak efektif untuk memisahkan campuran empat stereoisomer dari Fmoc-isoleusin.

Kata Kuci: Metil L-mandelat, Boc-DL-isoleusin, Fmoc-isoleusin, esterifikasi Steglich

\section{INTRODUCTION}

L-allo-Isoleucine (L-aIle) and D-isoleucine (DIle) occur as residues in some natural peptides, including aureobasidins. L- $a$ Ile is one of the nine residues in almost all aureobasidins structures and is an important requirement forantifungal activity (Takesako et al., 1996). D-Ile was needed as the starting material for the preparation of D-Hmp, one of the residues in the aureobasidin structures. Both compounds are commercially available but very expensive. It is likely that the difficulty in accessing these two isomers of isoleucine is one of the problems, which limits the total synthesis of many peptides including the aureobasidins. Many attempts, to address the problem by the synthesis and resolution of isoleucine mixtures, have been accomplished by researchers since the 1900s.

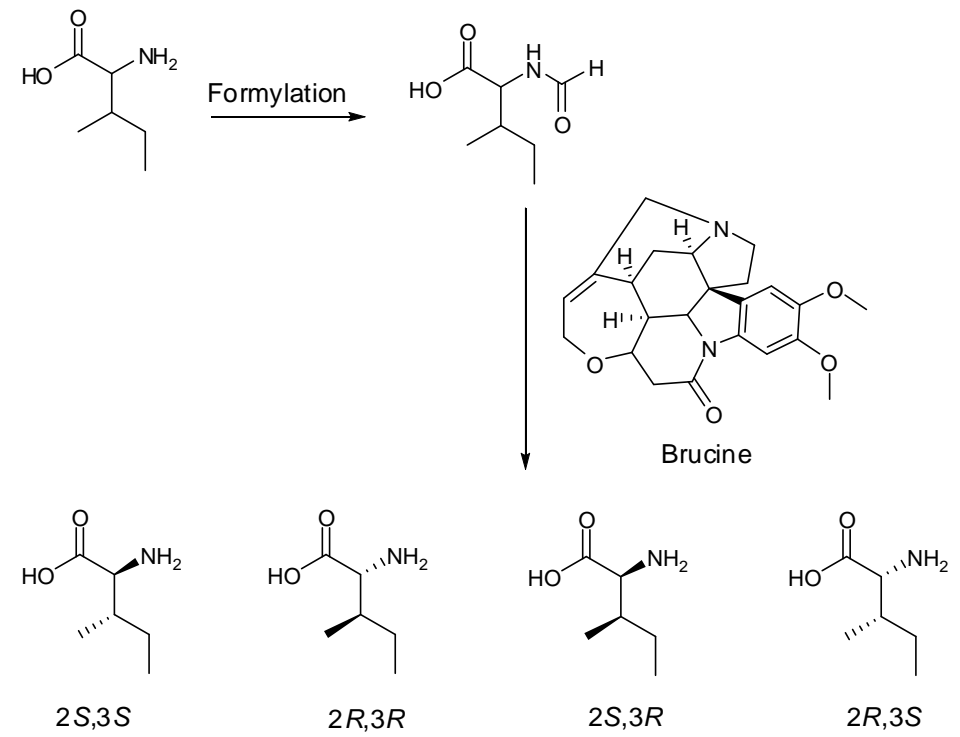

Scheme 1. Resolution of formylated isoleucine mixtures with brucine by Aderhalden \& Zeisset (1931) 
In 1907, Locquin described the resolution of a formylated mixture of L-Ile and D-Ile using brucine as a resolving agent (Locquin, 1907). Nearly 25 years later, the four stereoisomers of isoleucine were successfully resolved by Aderhalden \& Zeisset (1931) by the same method (Scheme 1). In the thesis of Hiatt from Illinois University in 1936 (Maharani, 2013), a formylated isoleucine mixture was resolved by using brucine, where each resolved isomer was epimerized by hot baryta (barium solution) to be resolved further by brucine to give the four stereoisomers of isoleucine. Greenstein et al. (1951) obtained all four isomers from enantiomers of isoleucine including DL-isoleucine and DL-alloisoleucine. Acetylation of enantiomers was followed by epimerization and enzymatic resolution. However, the development and scale up of this technique was difficult. At the same time, Huffman \& Ingersoll (1951) prepared acetylated enantiomers to be epimerized and then took advantage of (-)- $\alpha-$ fenchylamine in water to resolve acetylated DL-Ile. Another resolving agent, (-)- $\alpha$-phenylethylamine was found to be ineffective to separate the acetylated DLisomers. Acetylated-DL-aIle was only able to be resolved by using quinine in acetone. Other resolving agents, such as (-)- $\alpha$-fenchylamine, $\quad(-)-\alpha-$ phenylethylamine, brucine, cinchonine, (-)-ephedrine and (-)-desoxyephedrine, were not useful for the resolution of the acetylated-DL-aIle. More recently, Flouret \& Nakagawa (1975) used a pure isomer to get an isomer mixture through epimerization. The authors protected the isomer with several protecting groups such as isobutyryl (Ibu), carbonylbenzyloxy $(\mathrm{Cbz})$ and Boc. The protected isomer was epimerized to get a mixture which was then resolved by using $(S)$ - or $(R)$-phenylethylamine.

All of the techniques described to date do not offer a simple, low cost and reliable method for the resolution of isoleucine mixtures. Most of the time these methods give a low yield of desired product. Due to these problems, a simple and inexpensive synthetic method for the resolution of an isoleucine mixture was desired. This work was interested in trialling methyl-L-mandelate as a resolving agent, which is easily prepared from an inexpensive starting material.

Based on the literatures, the four isomers of isoleucine were obtained through epimerization of enantiomers (Hiatt 1936; Greenstein et al. 1951). Some researchers synthesised all four isomers, however most efforts could only produce two isomers. In the present study, we used a synthesis method of all four isomers described by Doyle et al. (1955).

\section{MATERIALS AND METHODS}

Optical rotation was measured with a PerkinElmer 141 Polarimeter or Atago POLAX-2L polarimeter at the $\mathrm{D}$ line of sodium $(589 \mathrm{~nm})$ in a 1 $\mathrm{dm}$ tube at the temperature and in the solvent indicated.

NMR spectra were performed on a BrukerAvance $300(300.13 \mathrm{MHz})$ instrument or a BrukerAvance $500 \quad(500.19 \mathrm{MHz})$ instrument. ${ }^{1} \mathrm{H}$ NMR were performed at $300.13 \mathrm{MHz}$ or $500.19 \mathrm{MHz}$ and ${ }^{13} \mathrm{C}$ were obtained at $75 \mathrm{MHz}$ or $125 \mathrm{MHz}$ (La Trobe University). Deuterochloroform (Cambridge Isotope Laboratories Inc.) was used as a solvent and as an internal standard unless otherwise stated. Chemical shifts were reported as $\delta$ values in parts per million (ppm) and coupling constants ( $\mathrm{J})$ in $\mathrm{Hz}$.

Low Resolution-Electrospray Ionisation Mass Spectrometry (LR-ESI) was carried out using a Bruker Daltonics (Germany) Esquire 6000 ion trap mass spectrometer at $300^{\circ} \mathrm{C}$ with a scan rate 5500 $\mathrm{m} / \mathrm{z} / \mathrm{sec}$ that was carried out at the Mass Spectrometry \& Proteomics Facility, La Trobe University. The molecular weights of all compounds were calculated based on calculations performed by Chem Draw Ultra V12.0.

\section{Procedures}

\section{$(S, R)-[(t-B u t o x y c a r b o n y l) a m i n o]-3(S, R)-3-$} methylpentanoic acid (2)

Commercially available DL-isoleucine mixture $\mathbf{1}$ (131 mg, $1.00 \mathrm{mmol})$ was dissolved in water $(2 \mathrm{~mL})$. To this solution was added $1 \mathrm{M}$ sodium hydroxide $(2$ $\mathrm{mL}$ ) and the solution was stirred and cooled to $5^{\circ} \mathrm{C}$. To the chilled solution was added Boc-anhydride (327 mg, $1.50 \mathrm{eq})$ in dioxane $(5 \mathrm{~mL})$ and cooling was continued. The reaction mixture was cooled at $0^{\circ} \mathrm{C}$ for $1 \mathrm{~h}$ and then it was allowed to warm to room temperature overnight. To this mixture was added water and the solution was extracted with ethyl acetate. The organic layer was back-washed with saturated sodium bicarbonate solution and the combined aqueous layers were acidified to $\mathrm{pH} 1$ by the addition of $10 \%$ hydrochloric acid solution and then it was extracted with ethyl acetate. The organic solution was dried $\left(\mathrm{MgSO}_{4}\right)$ and concentrated to give carbamate 2 as a colourless oil $(46.0 \mathrm{mg})$. Yield: $80 \%$; ${ }^{1} \mathrm{H}-\mathrm{NMR} \quad\left(300 \mathrm{MHz}, \mathrm{CDCl}_{3}\right) \quad \delta_{\mathrm{H}} \quad(\mathrm{ppm})$ (rotamers) $9.65(1 \mathrm{H}, \mathrm{bs}, \mathrm{COOH}), 5.09(1 \mathrm{H}, \mathrm{d}, J=8.4$ $\mathrm{Hz}, \mathrm{NH}), 5.03$ (1H, d, $J=9 \mathrm{~Hz}, \mathrm{NH}), 4.37-4.04(1 \mathrm{H}$, $\mathrm{m}, \mathrm{COCHNH}), 1.89\left(1 \mathrm{H}, \mathrm{bs}, \mathrm{CH}_{3} \mathrm{CHCH}_{2}\right), 1.40(9 \mathrm{H}$, $\left.\mathrm{s}, \mathrm{C}\left(\mathrm{CH}_{3}\right)_{3}\right), 1.48-1.36\left(1 \mathrm{H}, \mathrm{m}, \mathrm{CHCH} \mathrm{HCH}_{3}\right)$, 1.24$1.10\left(1 \mathrm{H}, \mathrm{m}, \mathrm{CHCH} \mathrm{HCH}_{3}\right), 0.93-0.82 \quad(6 \mathrm{H}, \mathrm{m}$; $\left.\mathrm{CH}_{3} \mathrm{CH}, \mathrm{CH}_{3} \mathrm{CH}_{2}\right) ;{ }^{13} \mathrm{C}-\mathrm{NMR}\left(75 \mathrm{MHz}, \mathrm{CDCl}_{3}\right) \delta_{\mathrm{C}}$ (ppm) 174.1, 174.0, 146.2, 84.7, 78.8, 57.3, 56.1, $37.4,37.2$, 28.5, 27.8, 25.7, 24.5, 15.0, 13.9, 11.3, 11.2.

\section{(S)-Methyl 2-hydroxy-2-phenylacetate (4)}

To a stirred solution of L-mandelic acid $3(1.52 \mathrm{~g}$, $10.00 \mathrm{mmol})$ in methanol $(25 \mathrm{~mL})$ was added concentrated sulfuric acid $(200 \mu \mathrm{L})$. The reaction mixture was refluxed for $3 \mathrm{~h}$ and then cooled to room temperature. To this mixture was added sodium 
bicarbonate (1-2 g) to neutralize any excess acid. Then, water was added and the solution was extracted with dichloromethane $(3 \times 5 \mathrm{~mL})$. The organic layer was dried with $\mathrm{MgSO}_{4}$, filtered and evaporated to give ester 4 as white crystals (1.15 g).Yield: 69\%; m.p. $51-53^{\circ} \mathrm{C}$ (lit.(Sigma-Aldrich) $56-58{ }^{\circ} \mathrm{C}$ ); $[\alpha]_{\mathrm{D}}{ }^{20}=$ $+150, c=2$ in methanol (lit.(Sigma-Aldrich) $[\alpha]_{\mathrm{D}}{ }^{20}=$ $+144, c=1$ in methanol); ESI-MS $\mathrm{m} / \mathrm{z}[\mathrm{M}+\mathrm{Na}]^{+}$ $189.0(100 \%) ;{ }^{1} \mathrm{H}-\mathrm{NMR}\left(300 \mathrm{MHz}, \mathrm{CDCl}_{3}\right) \delta_{\mathrm{H}}(\mathrm{ppm})$ 7.41-7.28 (5H, m, ArH), $5.16(1 \mathrm{H}, \mathrm{s}, \operatorname{ArCH}(\mathrm{OH}) \mathrm{CO})$, $3.74\left(3 \mathrm{H}, \mathrm{s}, \mathrm{OCH}_{3}\right), 3.49(1 \mathrm{H}, \mathrm{bs}, \mathrm{OH}) ;{ }^{13} \mathrm{C}-\mathrm{NMR}(75$ $\left.\mathrm{MHz}, \mathrm{CDCl}_{3}\right) \delta_{\mathrm{C}}(\mathrm{ppm}) 173.7,137.9,128.2,128.1$, 126.2, 72.5, 52.6.

$(2 S, 3 R)-(S)-2$-Carbomethoxy-1-phenylethyl 2-[(tbutoxycarbonyl)amino]-3-methylpentanoate (5a)

To a flask equipped with a calcium chloride drying tube, was added a solution of $2(450 \mathrm{mg}, 1.95$ $\mathrm{mmol})$ in dichloromethane $(6 \mathrm{~mL})$ and then ester 4 (324 $\mathrm{mg}, 1.95 \mathrm{mmol}$ ) and 4-dimethylaminopyridine (190 $\mathrm{mg}, 1.56 \mathrm{mmol}$ ). This stirred solution was cooled in an ice bath $\left(0^{\circ} \mathrm{C}\right)$. To this solution was added $N, N$ '-dicyclohexylcarbodiimide $(805 \mathrm{mg}, 3.9$ $\mathrm{mmol}$ ) over a $5 \mathrm{~min}$ period and stirring was continued for $5 \mathrm{~min}$. Stirring was then continued for $4 \mathrm{~h}$ at room temperature. The solution was filtered and the filtrate was washed with $0.5 \mathrm{~N}$ hydrochloric acid and then with saturated sodium bicarbonate solution. The organic layer was dried $\left(\mathrm{MgSO}_{4}\right)$ and evaporated to give a residue. The residue was purified by flash column chromatography (hexane-ethyl acetate) resulting in isolation of two diastereoisomers, 5a $(190 \mathrm{mg})$ and $\mathbf{5 b}(222 \mathrm{mg})$ as colourless oils. 5a Yield: $25 \%$; $[\alpha]_{\mathrm{D}}{ }^{20}=+27.5, c=2$ in dichloromethane; ${ }^{1} \mathrm{H}-\mathrm{NMR}\left(300 \mathrm{MHz}, \mathrm{CDCl}_{3}\right) \delta_{\mathrm{H}}(\mathrm{ppm}) 7.42-7.36(5 \mathrm{H}$, $\mathrm{m}, \operatorname{ArH}), 5.91(1 \mathrm{H}, \mathrm{s}, \operatorname{ArCHO}), 4.95(1 \mathrm{H}, \mathrm{d}, J=9.0$ $\mathrm{Hz}, \mathrm{COCHNH}), 4.50-4.47$ (1H, m, COCHNH), 3.69 $\left(3 \mathrm{H}, \mathrm{s}, \mathrm{OCH}_{3}\right), 2.13\left(1 \mathrm{H}, \mathrm{bs}, \mathrm{CH}_{3} \mathrm{CHCH}_{2}\right), 1.38(9 \mathrm{H}$, s, $\left.\mathrm{C}\left(\mathrm{CH}_{3}\right)_{3}\right), 1.52-1.21\left(2 \mathrm{H}, \mathrm{m}, \mathrm{CHCH}_{2} \mathrm{CH}_{3}\right), 0.98-$ $0.93\left(6 \mathrm{H}, \mathrm{m}, \mathrm{CH}_{3} \mathrm{CH}, \mathrm{CH}_{3} \mathrm{CH}_{2}\right) ;{ }^{13} \mathrm{C}-\mathrm{NMR}(75 \mathrm{MHz}$, $\left.\mathrm{CDCl}_{3}\right) \delta_{\mathrm{C}}(\mathrm{ppm}) 172.0,168.6,155.3,132.9,128.9$, 128.4, 127.2, 79.6, 74.5, 56.1, 52.1, 37.1, 27.9, 25.9, 13.7, 11.4. 5b Yield: $30 \%$; $[\alpha]_{\mathrm{D}}{ }^{20}=+32.5, c=2$ in dichloromethane; ${ }^{1} \mathrm{H}-\mathrm{NMR}\left(300 \mathrm{MHz}, \mathrm{CDCl}_{3}\right) \delta_{\mathrm{H}}$ (ppm) 7.43-7.35 (5H, m, ArH), 5.95 (1H, s, ArCHO), 4.96-4.92 (1H, m, COCHNH), 4.42-4.38 $(1 \mathrm{H}, \mathrm{m}$, $\mathrm{COCHNH}), 3.71\left(3 \mathrm{H}, \mathrm{s}, \mathrm{OCH}_{3}\right), 1.91(1 \mathrm{H}, \mathrm{bs}$, $\left.\mathrm{CH}_{3} \mathrm{CHCH}_{2}\right), 1.41\left(2 \mathrm{H}, \mathrm{d}, J=2.7 \mathrm{~Hz}, \mathrm{CHCH}_{2} \mathrm{CH}_{3}\right)$, $1.38\left(9 \mathrm{H}, \mathrm{s}, \mathrm{C}\left(\mathrm{CH}_{3}\right)_{3}\right), 0.98-0.90\left(3 \mathrm{H}, \mathrm{m}, \mathrm{CH}_{3} \mathrm{CH}\right)$, $0.84\left(3 \mathrm{H}, \mathrm{t}, J=7.2 \mathrm{~Hz}, \mathrm{CH}_{3} \mathrm{CH}_{2}\right) ;{ }^{13} \mathrm{C}-\mathrm{NMR}(75$ $\left.\mathrm{MHz}, \mathrm{CDCl}_{3}\right) \delta_{\mathrm{C}}(\mathrm{ppm}) 171.0,168.4,155.0,133.2$, $128.9,128.3,127.2,79.4,74.4,57.6,52.2,37.5,27.8$, 24.4, 15.0, 11.7 .

\section{(2S,3R)-Methyl 2-[(t-butoxycarbonyl)amino]-3- methylpentanoate (6a)}

Under an $\mathrm{N}_{2}$ atmosphere, 5a (190 mg) and potassium carbonate (2 grains) were dissolved in methanol $(12 \mathrm{~mL})$. The progress of the reaction was monitored by TLC. After the reaction was complete, the reaction mixture was dissolved in dichloromethane and extracted with water. The organic phase was purified using flash column chromatography (hexane:ethyl acetate) and this afforded 6a as a colourless oil $(84.0 \mathrm{mg})$. Yield: $68 \%$; $[\alpha]_{\mathrm{D}}{ }^{20}=+14.75, c=2$ in methanol; ESI-MS $\mathrm{m} / \mathrm{z}$ $\left.[\mathrm{M}+\mathrm{K}]^{+} 284.0(100 \%)\right] ;{ }^{1} \mathrm{H}-\mathrm{NMR}\left(300 \mathrm{MHz}, \mathrm{CDCl}_{3}\right.$ ) $\delta_{\mathrm{H}}(\mathrm{ppm}) 4.94(1 \mathrm{H}, \mathrm{d}, J=9.0 \mathrm{~Hz}, \mathrm{COCHNH}), 4.31$ $(1 \mathrm{H}, \mathrm{dd}, J=9.0,3.6 \mathrm{~Hz}, \mathrm{COCHNH}), 3.70(3 \mathrm{H}, \mathrm{s}$, $\left.\mathrm{CH}_{3} \mathrm{O}\right), 1.88-1.80\left(1 \mathrm{H}, \mathrm{m}, \mathrm{CH}_{3} \mathrm{CHCH}_{2}\right), 1.40(9 \mathrm{H}, \mathrm{s}$, $\left.\mathrm{C}\left(\mathrm{CH}_{3}\right)_{3}\right), 1.45-1.31\left(1 \mathrm{H}, \mathrm{m}, \mathrm{CHCH} \mathrm{HCH}_{3}\right), 1.19-1.07$ $\left(1 \mathrm{H}, \mathrm{m}, \mathrm{CHCH} \mathrm{HCH}_{3}\right), 0.90(3 \mathrm{H}, \mathrm{t}, J=10.2 \mathrm{~Hz}$, $\left.\mathrm{CH}_{3} \mathrm{CH}\right), 0.83\left(3 \mathrm{H}, \mathrm{d}, \mathrm{J}=5.2 \mathrm{~Hz}, \mathrm{CH}_{3} \mathrm{CH}_{2}\right) ;{ }^{13} \mathrm{C}-$ NMR $\left(75 \mathrm{MHz}, \mathrm{CDCl}_{3}\right) \delta_{\mathrm{C}}(\mathrm{ppm}) 172.9,155.4,79.4$, 56.4, 51.6, 37.3, 27.9, 25.7, 14.0, 11.3.

\section{(2R,3S)-Methyl 2-[(t-butoxycarbonyl)amino]-3- methylpentanoate $(6 \mathrm{~b})$}

A similar procedure was carried out on $\mathbf{5 b}(222$ $\mathrm{mg}$ ) to give $\mathbf{6 b}$ as a colourless oil $(59.0 \mathrm{mg})$. Yield: $41 \% ;[\alpha]_{\mathrm{D}}{ }^{20}=-11.11, c=1$ in methanol; ESI-MS $\mathrm{m} / \mathrm{z}$ $[\mathrm{M}+\mathrm{K}]^{+} 284.1$ (100\%)]; ${ }^{1} \mathrm{H}-\mathrm{NMR} \quad(300 \mathrm{MHz}$, $\left.\mathrm{CDCl}_{3}\right) \delta_{\mathrm{H}}(\mathrm{ppm}) 5.00(1 \mathrm{H}, \mathrm{d}, \quad J=7.5 \mathrm{~Hz}$, $\mathrm{COCHNH}), 4.33-4.20(1 \mathrm{H}, \mathrm{m}, \mathrm{COC} H \mathrm{NH}), 3.72(3 \mathrm{H}$, s, $\left.\mathrm{CH}_{3} \mathrm{O}\right), 1.80-1.75\left(1 \mathrm{H}, \mathrm{bs}, \mathrm{CH}_{3} \mathrm{CHCH}_{2}\right), 1.43(9 \mathrm{H}$, s, $\left.\mathrm{C}\left(\mathrm{CH}_{3}\right)_{3}\right), 1.49-1.32\left(1 \mathrm{H}, \mathrm{m}, \mathrm{CHCH} \mathrm{HCH}_{3}\right), 1.20-$ $1.06\left(1 \mathrm{H}, \mathrm{m}, \mathrm{CHCH} \mathrm{HCH}_{3}\right) \quad 0.92-0.78 \quad(6 \mathrm{H}, \mathrm{m}$, $\left.\mathrm{CH}_{3} \mathrm{CH}, \mathrm{CH}_{3} \mathrm{CH}_{2}\right) ;{ }^{13} \mathrm{C}-\mathrm{NMR}\left(75 \mathrm{MHz}, \mathrm{CDCl}_{3}\right) \delta_{\mathrm{C}}$ (ppm) 172.5, 155.1, 79.3, 57.4, 51.5, 37.6, 27.9, 24.6, 15.0, 11.1.

The four isomers of isoleucine were synthesized via a two-step literature method (Doyle et al. 1955).

\section{(E)-4-(Butan-2-ylidene)-2-phenyloxazol-5(4H)-one (10)}

To a solution of hippuric acid $(20.0 \mathrm{~g}, 110 \mathrm{mmol})$ and anhydrous sodium acetate $(9.00 \mathrm{~g}, 110 \mathrm{mmol})$ in methyl ethyl ketone $(478 \mathrm{~mL})$ was added acetic anhydride $(28 \mathrm{~mL})$ dropwise during a $30 \mathrm{~min}$ period. Then, the solution was refluxed for $2 \mathrm{~h}$. The resulting orange solution was distilled to recover the methyl ethyl ketone (b.p. $80-84^{\circ} \mathrm{C}$ ). The residual solution was evaporated and the residue was dissolved in saturated sodium bicarbonate solution until effervescence ceased and then it was extracted with ether. The organic layer was evaporated to give a crude. This crude was purified on a flash chromatography column eluting with $4 \%$ ethyl acetate in hexane to give compound $\mathbf{1 0}$ as a yellow oil (7.35 g). Yield: 32\%; ESI-MS $m / z[\mathrm{M}+\mathrm{H}]^{+} 216.2$ $(100 \%) ;{ }^{1} \mathrm{H}-\mathrm{NMR}\left(300 \mathrm{MHz}, \mathrm{CDCl}_{3}\right) \delta_{\mathrm{H}}$ (ppm) 8.03 $(2 \mathrm{H}, \mathrm{d}, J=6.9 \mathrm{~Hz}, \mathrm{ArH}), 7.55-7.43$ (3H, m, ArH), $2.86\left(1 \mathrm{H}, \mathrm{q}, J=7.5 \mathrm{~Hz}, \mathrm{CCHHCH}_{3}\right), 2.75(1 \mathrm{H}, \mathrm{q}, J=$ $\left.7.5 \mathrm{~Hz}, \mathrm{CCH} \mathrm{HCH}_{3}\right), 2.35\left(3 \mathrm{H}, \mathrm{bs}, \mathrm{CH}_{3} \mathrm{C}\right), 1.25-1.13$ $\left(3 \mathrm{H}, \mathrm{m}, \mathrm{CH}_{3} \mathrm{CH}_{2}\right) ;{ }^{13} \mathrm{C}-\mathrm{NMR}\left(75 \mathrm{MHz}, \mathrm{CDCl}_{3}\right) \delta_{\mathrm{C}}$ (ppm) 165.4, 164.7, 159.1, 159.0, 158.8, 158.4, $132.0,131.9,130.9,130.8,128.4,127.3,127.2$, $125.8,28.7,25.7,19.7,16.9,12.0,11.8$. 


\section{Isoleucine mixture (11)}

To a solution of $\mathbf{1 0}(2.71 \mathrm{~g}, 12.6 \mathrm{mmol})$ in acetic acid $(17.8 \mathrm{~mL})$ was added hydroiodic acid $(12.7 \mathrm{~mL}$, $55 \%)$ and red phosphorus $(760 \mathrm{mg})$. The reaction mixture was then refluxed for $90 \mathrm{~min}$ and the reaction mixture was filtered and evaporated to give a crude that was partitioned between water and ether. The aqueous layer was evaporated and the residue was dissolved in ethanol. The solution was then adjusted to $\mathrm{pH}$ 6. The white precipitate that formed was removed by filtration. Then calcium hydroxide $(1.40$ g) in water was added to the white precipitate and the solution was heated until boiling for $1 \mathrm{~h}$. To remove the calcium from the filtrate, the filtrate was then treated with ammonium bicarbonate and filtered. Evaporation of the filtrate resulted in 11 (510 mg, $21 \%$ yield).

\section{2-[(N-Fluorenylmethyloxycarbonyl)amino]-3- methylpentanoic acid (12)}

An isoleucine mixture $11(1.00 \mathrm{~g}, 7.60 \mathrm{mmol})$ was dissolved in aqueous sodium hydroxide (304 mg, $76.0 \mathrm{mmol}$ in $38 \mathrm{~mL}$ water). To this solution was added $\quad N$-(9-fluorenylmethoxycarbonyloxy) succinimide $(2.56 \mathrm{~g}, 7.60 \mathrm{mmol})$ in acetone $(38 \mathrm{~mL})$ in several portions. Once the addition was complete, sodium bicarbonate $(638 \mathrm{mg}, 7.60 \mathrm{mmol})$ was added to the solution. The solution was stirred until it turned clear. The clear solution was cooled and adjusted to $\mathrm{pH} 2$ by the addition of concentrated hydrochloric acid. Then the solution was partitioned between saturated sodium bicarbonate solution and ethyl acetate. The organic solution was dried $\left(\mathrm{MgSO}_{4}\right)$ and concentrated to give 12 (1.91 g).Yield: 71\%; ESI-MS $\mathrm{m} / \mathrm{z}[\mathrm{M}+\mathrm{Na}]^{+} 376.1$ (100\%); ${ }^{1} \mathrm{H}-\mathrm{NMR}$ and ${ }^{13} \mathrm{C}-\mathrm{NMR}$ showed a mixture of isoleucines.

\section{$(2 S, 3 R)-(S)-2-M e t h o x y-2-0 x o-1-p h e n y l e t h y l-2-$ [( $N$-fluorenylmethyloxycarbonyl)amino]-3- methylpentanoate (13a)}

To a flask equipped with a calcium chloride drying tube was added a solution of $\mathbf{1 2}(1.77 \mathrm{~g}, 5.01$ mmol) in dichloromethane $(18 \mathrm{~mL}), 4(2.54 \mathrm{~g}, 15.3$ $\mathrm{mmol})$ and 4-dimethylaminopiperidine $(500 \mathrm{mg}, 3.01$ $\mathrm{mmol})$. This stirred solution was cooled in an ice bath $\left(0^{\circ} \mathrm{C}\right)$ and to this solution was added $N, N^{\prime}-$ dicyclohexylcarbodiimide $(1.05 \mathrm{~g}, 5.01 \mathrm{mmol})$ over a $5 \mathrm{~min}$ period. Stirring was then continued for $4 \mathrm{~h}$ at room temperature. The solution was filtered and the filtrate was washed successively with $0.5 \mathrm{~N}$ hydrochloric acid and saturated sodium bicarbonate solution. The organic layer was dried $\left(\mathrm{MgSO}_{4}\right)$ and evaporated to give a residue. The residue was purified by flash column chromatography (dichloromethane:hexane: ethyl acetate $=3.5: 6: 0.5$ which was followed by $10-20 \%$ ethyl acetate in hexane) resulting in two diastereoisomers, 13a (795 $\mathrm{mg})$ and 13b (300 $\mathrm{mg})$ as colourless oils. 13a Yield: $40 \% ;[\alpha]_{\mathrm{D}}{ }^{20}=+60.0, c=1$ in dichloromethane; ESIMS $m / z[\mathrm{M}+\mathrm{H}]^{+} 502.1$ (100\%); ${ }^{1} \mathrm{H}-\mathrm{NMR}(300 \mathrm{MHz}$,
$\left.\mathrm{CDCl}_{3}\right) \delta_{\mathrm{H}}(\mathrm{ppm}) 7.75(2 \mathrm{H}, \mathrm{d}, J=7.5 \mathrm{~Hz}, \mathrm{ArH}), 7.59$ $(2 \mathrm{H}, \mathrm{d}, J=7.2 \mathrm{~Hz}, \mathrm{ArH}), 7.44-7.36(7 \mathrm{H}, \mathrm{m}, \mathrm{ArH})$, $7.27(2 \mathrm{H}, \mathrm{t}, J=7.2 \mathrm{~Hz}, \mathrm{ArH}), 5.94(1 \mathrm{H}, \mathrm{s}, \mathrm{ArCHO})$, $4.64(1 \mathrm{H}, \mathrm{dd}, J=4.5,9.0 \mathrm{~Hz}, \mathrm{OCH} \mathrm{HCH}), 4.38(2 \mathrm{H}$, $\mathrm{d}, J=6.9 \mathrm{~Hz}, \mathrm{OCH} H \mathrm{CH}$; ArCHAr $), 4.22(1 \mathrm{H}, \mathrm{t}, J=$ $6.9 \mathrm{~Hz}, \mathrm{COCHNH}), 3.71\left(3 \mathrm{H}, \mathrm{s}, \mathrm{CH}_{3} \mathrm{O}\right), 2.18(1 \mathrm{H}, \mathrm{bs}$, $\mathrm{CH}_{3} \mathrm{CHCH}_{2}$ ), 1.59-1.49 (1H, m, CHCH $\left.\mathrm{HCH}_{3}\right), 1.39-$ $1.22\left(1 \mathrm{H}, \mathrm{m}, \mathrm{CHCH} \mathrm{CCH}_{3}\right), 1.06-0.85(6 \mathrm{H}, \mathrm{m}$, $\left.\mathrm{CH}_{3} \mathrm{CH} ; \mathrm{CH}_{3} \mathrm{CH}_{2}\right) ;{ }^{13} \mathrm{C}-\mathrm{NMR}\left(75 \mathrm{MHz}, \mathrm{CDCl}_{3}\right) \delta_{\mathrm{C}}$ (ppm) 171.2, 168.5, 155.7, 143.6, 143.4, 140.9, $132.9,129.1,128.5,127.3,127.2,126.7,124.8$, 119.6, 74.8, 66.8, 57.9, 52.3, 46.8, 37.8, 24.4, 14.9, 11.4. 13b Yield: $17 \%$; $[\alpha]_{\mathrm{D}}{ }^{20}=+45.0, c=1$ in dichloromethane; ESI-MS $\mathrm{m} / z \quad[\mathrm{M}+\mathrm{H}]^{+} \quad 502.1$ (100\%); ${ }^{1} \mathrm{H}-\mathrm{NMR}\left(300 \mathrm{MHz}, \mathrm{CDCl}_{3}\right) \delta_{\mathrm{H}}$ (ppm) 7.71 $(1 \mathrm{H}, \mathrm{d}, J=7.2 \mathrm{~Hz}, \mathrm{ArH}), 7.66(2 \mathrm{H}, \mathrm{d}, J=7.8 \mathrm{~Hz}$, ArH), $7.59(1 \mathrm{H}, \mathrm{d}, J=7.2 \mathrm{~Hz}, \mathrm{ArH}), 7.45-7.40(7 \mathrm{H}$, $\mathrm{m}, \operatorname{ArH}), 7.30(2 \mathrm{H}, \mathrm{t}, J=6.9 \mathrm{~Hz}, \mathrm{ArH}), 5.97(1 \mathrm{H}, \mathrm{d}, J$ $=14.4 \mathrm{~Hz}, \mathrm{ArCHO}), 4.74-4.56(1 \mathrm{H}, \mathrm{m}, \mathrm{OCH} \mathrm{HCH})$, $4.39(2 \mathrm{H}, \mathrm{d}, J=6.6 \mathrm{~Hz}, \mathrm{OCH} H \mathrm{CH}$; ArCHAr $), 4.23$ $(1 \mathrm{H}, \mathrm{t}, J=6.9 \mathrm{~Hz}, \mathrm{COCHNH}), 3.71\left(3 \mathrm{H}, \mathrm{s}, \mathrm{CH}_{3} \mathrm{O}\right)$, $2.19\left(1 \mathrm{H}, \quad\right.$ bs, $\left.\mathrm{CH}_{3} \mathrm{CHCH}_{2}\right), 1.63-1.38(1 \mathrm{H}, \mathrm{m}$, $\left.\mathrm{CHCHHCH}_{3}\right), 1.36-1.23\left(1 \mathrm{H}, \mathrm{m}, \mathrm{CHCH} \mathrm{HCH}_{3}\right), 1.10-$ 0.97 (6H, m, $\left.\mathrm{CH}_{3} \mathrm{CH} ; \mathrm{CH}_{3} \mathrm{CH}_{2}\right) ;{ }^{13} \mathrm{C}-\mathrm{NMR}(75 \mathrm{MHz}$, $\left.\mathrm{CDCl}_{3}\right) \delta_{\mathrm{C}}(\mathrm{ppm}) 171.6,168.5,156.1,143.6,143.4$, $140.9,132.8,129.7,129.1,128.6,128.5,127.3$, 126.7, 124.7, 119.6, 74.7, 66.8, 56.8, 52.3, 46.8, 37.7, $24.2,13.8,11.4$.

\section{RESULTS AND DISCUSSION \\ Resolution of Boc-DL-isoleucine}

In the first attempt, commercially available DLisoleucine 1 was initially protected with Bocanhydride to give Boc-isoleucine 2 (Scheme 2). Bocand Fmoc-protected amino acids are preferred, as these compounds are then ready for either solutionor solid-phase peptide synthesis. The DL-isoleucine was protected based on a reported protocol (Umezawa et al. 2010) affording 91\% yield of the product, which was confirmed by ${ }^{1} \mathrm{H}$ - and ${ }^{13} \mathrm{C}-\mathrm{NMR}$ which showed the desired compound. The presence of a methyl signal at $\delta_{\mathrm{H}} 1.40 \mathrm{ppm}\left(\delta_{\mathrm{C}} 27.8\right.$ and 28.5 ppm) and one additional carbonyl signal at $\delta_{\mathrm{C}} 146.2$ ppm supported the presence of the Boc group.

The resolving agent of methyl L-mandelate $\mathbf{4}$ was prepared from L-mandelic acid $\mathbf{3}$ employing a simple Fisher acidic esterification and this gave a good yield of the corresponding ester 4 (Scheme 3). The presence of a singlet signal in the ${ }^{1} \mathrm{H}-\mathrm{NMR}$ spectrum at $\delta_{\mathrm{H}} 3.70 \mathrm{ppm}$ and in the ${ }^{13} \mathrm{C}-\mathrm{NMR}$ spectrum at $\delta_{\mathrm{C}}$ $52.6 \mathrm{ppm}$ confirmed the presence of the methyl ester.

Boc-isoleucine $\mathbf{2}$ was reacted with methyl Lmandelate 4 by taking advantage of the Steglich esterification (Neises \& Steglich 1978) using DCC/DMAP in dichloromethane (Scheme 4) (Neises \& Steglich 1990).

The Steglich esterification method was chosen because the mildly basic conditions were compatible with the Boc protecting group. The reaction between Boc-isoleucine $\mathbf{2}$ and methyl L-mandelate $\mathbf{4}$ resulted 
<smiles>[Z]CC(C)C(NC(=O)OC(C)(C)C)C(=O)O</smiles>

Scheme 2 Boc-protection of DL-isoleucine, (a) $\mathrm{H}_{2} \mathrm{O}, \mathrm{NaOH}$, (Boc) $)_{2} \mathrm{O}$.<smiles>CCCCCCCC(=O)O</smiles>

3<smiles>COC(=O)[C@H](O)c1ccccc1</smiles>

4

Scheme 3 A preparation of methyl L-mandelate 4, (a) methanol, sulfuric acid.

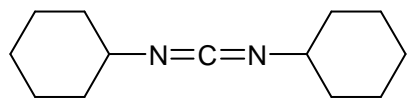

7<smiles>CN(C)c1ccncc1</smiles>

Figure 1 Structures of DCC 7 and DMAP 8.

in formation of two diastereomers of the mandelic esters $\mathbf{5 a}$ and $\mathbf{5 b}$ which were subsequently separated by flash column chromatography in $25 \%$ and $30 \%$ yield, respectively.

DCC 7 is a carbodiimide-based coupling reagent that is useful for the preparation of esters and amides (Figure 1). This reagent was reported by Sheehan \& Hess (1955) as being insensitive to moisture, without racemised products and resulting in a separable byproduct, $N, N^{\prime}$-dicyclohexyl urea, that has low solubility both in organic and aqueous phase. However, due to the insoluble by-product, DCCbased coupling reactions are inappropriate for solidphase peptide synthesis.

DMAP 8 (Figure 1) was added as a catalyst in order to activate the $O$-acylisourea intermediate (Neises \& Steglich 1978). This compound acts as an acyl transfer reagent and a subsequent reaction with an alcohol results in ester bond formation (Corey 2007). Unfortunately, undesirable levels of racemization can be produced when employed in excess and it has been shown that no more than 0.15 equivalents should be used (ChemPrep 2005; AAPPTec 2011). In DCC/DCI-mediated reactions, dichloromethane has been proven to be the optimal solvent for carbodiimide activation. A mixture of dichloromethane and DMF is often used for both the activation and the coupling steps.

Mechanistic studies on the Steglich esterification have been reported (Corey 2007). An $O$-acylisourea intermediate results from reaction between DCC and a carboxylic acid and this gives reactivity that is similar to the carboxylic acid anhydride. The intermediate was further activated by DMAP 8. DMAP 8 is a strong nucleophile that is more reactive than the alcohol itself and reacts with the $O$ acylisourea affording a reactive amide. The alcohol then adds to the activated carbonyl of the reactive amide to form the stable dicyclohexylurea (DHU) and the ester (Figure 2).

Table 1. Optical rotation data of Boc-protected isoleucine

\begin{tabular}{lc}
\hline \multicolumn{1}{c}{ Compound } & {$[\alpha]^{20}{ }_{\mathrm{D}}$} \\
\hline Boc-L-Ile methyl ester 6a & $+14.75(c 2$ in methanol $)$ \\
Boc-L-Ile methyl ester* & $+16.6(c 2$ in chloroform $)$ \\
Boc-D-Ile methyl ester 6b & $-11.11(c$ 1 in methanol $)$ \\
\hline *Widmer \& Lorenzi (1971) &
\end{tabular}

Methanolysis of each of the diastereomers $\mathbf{5 a}$ and $\mathbf{5 b}$ resulted in the corresponding methyl esters $\mathbf{6 a}$ and 6b (Scheme 4). Measurement of the optical rotation of the compounds also gave useful information (Table 1). The optical rotation value of the Boc-L-Ile methyl ester $\mathbf{6 a}$ in methanol was found to be close to the value of the same compound measured in chloroform. Both compounds were purified by flash chromatography and each was shown to be a single compound by ${ }^{1} \mathrm{H}$ - and particularly ${ }^{13} \mathrm{C}-\mathrm{NMR}$ that 


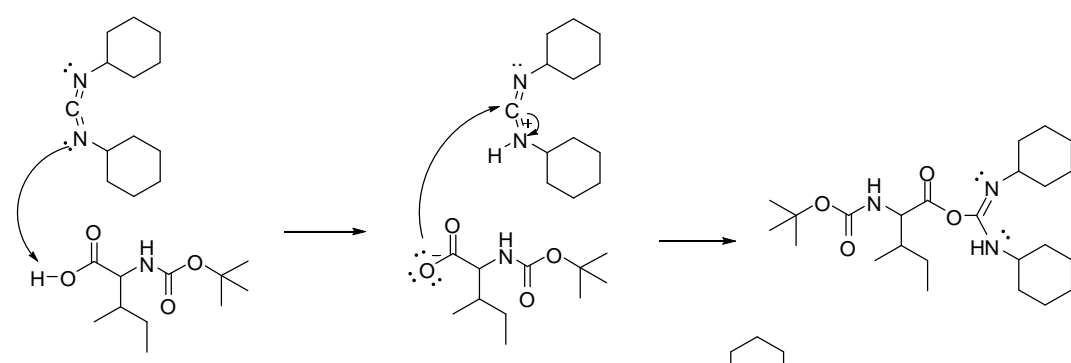

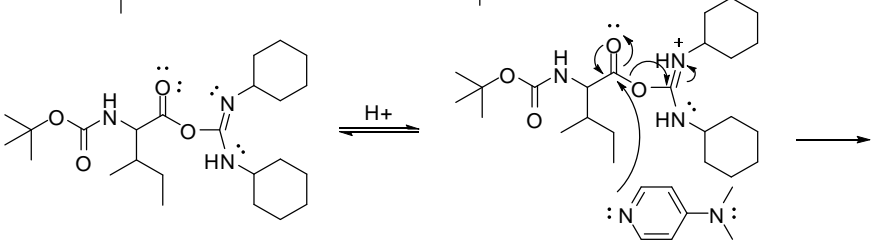
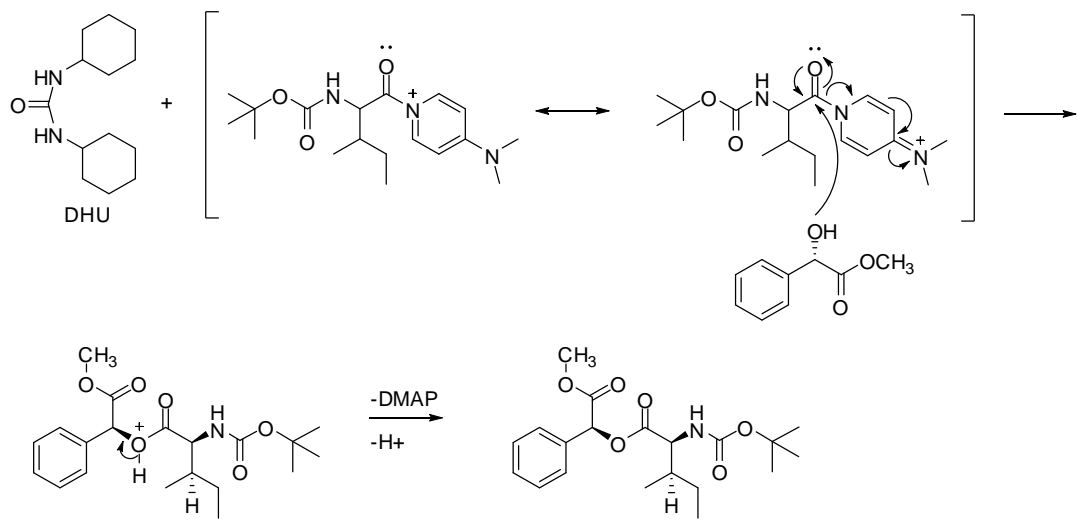

Figure 2. A mechanism for Steglich esterification between Boc-DL-isoleucine 2 and methyl L-mandelate 4 (adapted from Corey et al. 2007).<smiles>COC(=O)[C@H](O)c1ccccc1</smiles><smiles>CCC(C)C(NC(=O)OC(C)(C)C)C(=O)O</smiles><smiles>CC[C@H](C)[C@H](NC(=O)OC(C)(C)C)C(=O)O[C@H](C(=O)OC)c1ccccc1</smiles><smiles>CC[C@H](C)[C@H](NC(=O)OC(C)(C)C)C(=O)OC(C(=O)OC)c1ccccc1</smiles>

$5 b$<smiles>CC[C@@H](C)[C@H](C(=O)OC)[C@@H]([13CH2]C)NC(=O)OC(C)(C)C</smiles><smiles>CC[C@@H](C)[C@H](C(=O)OC)[C@H]([13CH2]C)NC(=O)OC(C)(C)C</smiles>

$6 a$

$6 b$

Scheme 4. Steglich esterification between Boc-DL-isoleucine 2 and methyl L-mandelate 4 and resolution of products, (a) $\mathrm{CH}_{2} \mathrm{Cl}_{2}$, DCC, DMAP. (b) $\mathrm{K}_{2} \mathrm{CO}_{3}$, methanol. 
showed a single set of peaks, which is a good sign to be a single stereoisomer.

Similar work carried out by Dumbre (2010 in Maharani 2013) using Fmoc-DL-isoleucine also found only two enantiomers from the chromatographic separation. Based on both of these initial investigations, it appeared that methyl Lmandelate $\mathbf{4}$ as a resolving agent was effective to achieve resolution of the isomers. To further study the ability of methyl L-mandelate 4 to resolve an isoleucine mixture, the developed resolution protocol was tested using a synthetic isoleucine mixture.

\section{Resolution of four stereoisomers of Fmoc- isoleucine \\ Synthesis of a mixture of all four isoleucine} isomers 11 was undertaken using the methodology developed by Doyle et al. (1955) This process occurs via an intermediate oxazolone $\mathbf{1 0}$ in $32 \%$ yield where reduction by red phosphorus and hydroiodic acid (HI) leads to the desired product mixture in 55\% yield (Scheme 5). The presence of the four isomers resulted from this synthesis has also been confirmed by Aurelio et al. (2006). It had been shown by ${ }^{13} \mathrm{C}$ NMR of the product mixture that doubling of all peaks with near equal intensity was occurring. All four possible isomers are shown in Figure 4.

Fmoc protection was then carried out on the isoleucine mixture using Fmoc- $O$-succinimide in basic conditions in $67 \%$ yield (Scheme 6). Steglich esterification using DCC/DMAP with 4 resulted in mandelic esters 13. These were separated by flash chromatography. Unfortunately, the expected four isomers were not obtained. The product mixture could only be separated into two isomers, 13a in $40 \%$ yield and 13b in $17 \%$ yield (Scheme 6).

Each isomer appeared to be a single enantiomer due to a single set of peaks shown in the ${ }^{1} \mathrm{H}$ and particularly ${ }^{13} \mathrm{C}$-NMR spectra. The optical rotation of each isomer is shown in Table 2. In fact, there are no reference of optical rotation of the $13 \mathbf{a}$ and $13 \mathbf{b}$, reported in the literature. It was assumed that isolation of the other two isomers probably failed during the purification step. In the purification step, 13a and 13b were found to be two major isomers in the mixture, while the other two isomers might be remained as minor fractions, which are barely separated and analyzed. Another possibility was that the methyl L-mandelate 4 could not resolve the four isomers of isoleucine.<smiles>CCCCCOC(=O)C(N)C(C)CC</smiles>

Scheme 5 Synthesis of the isoleucine mixture. (a) sodium acetate, methyl ethyl ketone, acetic anhydride. (b) acetic acid, HI, red phosphorus.<smiles>CC[C@H](C)[C@H](N)C(=O)O</smiles>

$2 S, 3 S$<smiles>CC[C@H](C)[C@H](N)C(=O)O</smiles>

$2 R, 3 R$<smiles>CC[C@H](C)[C@H](N)C(=O)O</smiles>

$2 S, 3 R$<smiles>CC[C@H](C)[C@H](N)C(=O)O</smiles>

$2 R, 3 S$

Figure 4. Four isomers of isoleucine.

Table 2. Optical rotation data of Fmoc-protected isoleucine

\begin{tabular}{cc}
\hline Compound & {$[\alpha]^{20} \mathrm{D}$} \\
\hline Fmoc-L-Ile/aIle-methyl L-mandelate 13a & $+60.0(c=1$ in dichloromethane $)$ \\
Fmoc-D-Ile/aIle-methyl L-mandelate 13b & $+45.0(c=1$ in dichloromethane $)$
\end{tabular}


<smiles>CCC(C)C(NC(=O)OCC1c2ccccc2-c2ccccc21)C(=O)O</smiles><smiles>COC(=O)[C@@H](OC(=O)[C@H]([14CH3])NC(=O)OCC1c2ccccc2-c2ccccc21)c1ccccc1</smiles>

$13 a$

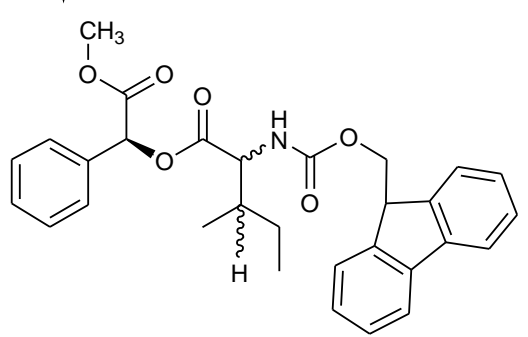

$13 b$

Scheme 6 A resolution of Fmoc-isoleucine mixture 11 with methyl-L-mandelate 4, (a) NaOH in water, FmocOSu in acetone, $\mathrm{NaHCO}_{3}$, (b) $\mathrm{CH}_{2} \mathrm{Cl}_{2}, \mathrm{DCC}$, DMAP, 4.

\section{CONCLUSIONS}

The resolution of commercial DL-isoleucine was successfully undertaken by methyl L-mandelate 4. However, the resolving agent could not successfully resolve the four stereoisomers of isoleucine. Anew method that can cope with the problems in the resolution of isoleucine mixture still needs to be developed.

\section{Acknowledgements}

We would like to acknowledge the support from La Trobe University, Melbourne, Australia for the utilization of some instruments mentioned on the material and methods section for the present study.

\section{DAFTAR PUSTAKA}

AAPPTec. 2011. Coupling Reagents [Online]. http://www.aapptec.com/coupling-reagents-i148.html: AAPPTEC. [Accessed 2011].

Abderhalden, E. \& Zeisset, W. (1931). Spaltung von synthetisch dargestelltem isoleucin in seine vier optisch-aktiven komponenten, nämlich $1-(+)$ und $\mathrm{d}-(-)$ isoleucin, sowie $\mathrm{d}-(-)$ und $\mathrm{l}-(+)$ alloisoleucin. Hoppe-Seyler's Zeitschrift für physiologische Chemie. 195(3-6): 121-131.

Aurelio, L., Brownlee, R.T.C., Dang, J., Hughes, A.B. \& Polya, G.M. (2006). Determination of the Complete Absolute Configuration of Petriellin A. Australian Journal of Chemistry. 59(6): 407-414.

ChemPep. 2005. Fmoc Solid Phase peptide Synthesis. http://www.chempep.com/ChemPepFmoc-Solid-Phase-Peptide-Synthesis.htm. [Accessed 2012].
Corey, E. J., Czako, B. \& Kurti, L. (2007). Molecule and Medicine. London: John Wiley and Sons Ltd.

Doyle, F.P., Holland, D.O., Marflitt, W., Nayler, J.H.C. and O'Connor, C.M., 1955. Experiments in the synthesis of DL-iso leucine. Journal of the Chemical Society (Resumed). 1719-1723.

Flouret, G. \& Nakagawa, S.H. (1975). On a convenient resolution method for the preparation of isoleucine optical isomers. Journal of Organic Chemistry. 40(18): 26352637.

Greenstein, J.P., Levintow, L., Baker, C.G. \& White, J. (1951). Preparation of the four stereoisomers of isoleucine. Journal of Biological Chemistry. 188: 647-63.

Huffman, W.A.H. \& Ingersoll, A.W. (1951). The resolution of amino acids. II. Isoleucine, alloisoleucine, leucine, and norleucine. Journal of American Chemical Society. 73: 3366-3369.

Locquin, R., (1907). Dédoublement de l'acide aamino-b-methyl-b-ethyl-propionique en ses deux inverses optiques. Bulletin de la Société Chimique de France. 1: 595-601.

Neises, B. \& Steglich, W. (1978). Simple method for the esterification of carboxylic acids. Angewandte Chemie International Edition in English. 17(7): 522-524.

Neises, B. \& Steglich, W. 1990. Esterification of carboxylic acids with dicyclohexylcarbodiimide 14-dimethylaminopyridine: tert-butyl ethyl fumarate. Organic Syntheses. 63: 183-183. 
Maharani, R. 2013. Studies of Highly N-Methylated Cyclodepsipeptides, the Aureobasidins. Doctoral Thesis, La Trobe University.

Sheehan, J. C. \& Hess, G. P. 1955. A new method of forming peptide bonds. Journal of the American Chemical Society. 77(4): 1067-1068.

Sigma-Aldrich. Melting Point of Methyl (S)-(+)Mandelate. http://www.sigmaaldrich.com/ catalog/product/aldrich/251542?lang=en\&regio n=AU. Sigma-Aldrich USA. [Accessed 2013].

Takesako, K., Mizutani, S., Sakakibara, H., Endo, M., Yoshikawa, Y., Masuda, T., Sono-Koyama,
E. \& Kato, I. (1996). Precursor directed biosynthesis of aureobasidins. The Journal of Antibiotics. 49(7): 676-681.

Umezawa, N., Matsumoto, N., Iwama, S., Kato, N. \& Higuchi, T. 2010. Facile synthesis of peptideporphyrin conjugates: Towards artificial catalase. Bioorganic \& Medicinal Chemistry. 18(17): 6340-6350.

Widmer, U. \& Lorenzi, G.P. (1971). Conformation in solution of some oligomeric peptides derived from L-isoleucine. Chimia. 25(7): 236-238. 